\title{
Prevalence and intensity of pentastomid infection in two species of snakes from northeastern Brazil
}

\author{
Almeida, WO. ${ }^{\mathrm{a} *}$, Vasconcellos, . $^{\mathrm{b}}$, Lopes, $S G .^{\mathrm{a}}$ and Freire, EMX. ${ }^{\mathrm{b}}$ \\ a Departamento de Ciências Físicas e Biológicas, Universidade Regional do Cariri, \\ R. Cel. Antônio Luiz, 1161, CEP 63100-000, Crato, CE, Brazil

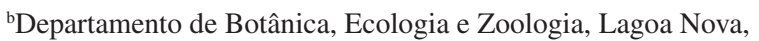 \\ Universidade Federal do Rio Grande do Norte, CEP 59072-970, Natal, RN, Brazil \\ *e-mail: walmeida@urca.br
}

Received March 3, 2006 - Accepted May 29, 2006 - Distributed November 30, 2007

(With 1 figure)

\begin{abstract}
This study aimed to evaluate the infection rates of snakes by pentastomids in the semi-arid region of Brazil. Fifteen snakes (four Micrurus ibiboboca (Merrem, 1820) and eleven Philodryas nattereri Steindachner, 1870) were collected between January and April of 2005, in the municipality of Crato ( $07^{\circ} 14^{\prime} \mathrm{S}$ and $\left.39^{\circ} 24^{\prime} \mathrm{W}\right)$, State of Ceará, Brazil. Laboratorial analysis of the respiratory tracts of the sampled snakes indicated differences in host infection rates: four individuals of $P$. nattereri (36.4\%) were infected by Cephalobaena tetrapoda Heymons, 1922 (mean infection intensity $1.5 \pm 0.28,1-2)$ and three specimens $(27.3 \%)$ by Raillietiella furcocerca (Diesing, 1863$)(2.3 \pm 1.32,1-5)$. Only one individual of $M$. ibiboboca $(25 \%)$ was infected by a non-identified species of Raillietiella sp. These are the first data on pentastomid infection in snakes in Northeastern Brazil and both snake species comprise new host records for the pentastomids. The results also indicate that the generalist parasites $C$. tetrapoda and $R$. furcocerca share their definitive hosts.

Keywords: endoparasites, Cephalobaena, Raillietiella, neotropical region.
\end{abstract}

\section{Prevalência e intensidade de infecção por pentastomídeos em duas espécies de cobras do nordeste brasileiro}

\section{Resumo}

Este artigo visou compreender as taxas de infecção por pentastomídeos em serpentes na região do semi-árido brasileiro. Quinze serpentes (quatro Micrurus ibiboboca (Merrem, 1820) e onze Philodryas nattereri Steindachner, 1870) foram coletadas entre os meses de janeiro e abril de 2005, no município do Crato ( $07^{\circ} 14^{\prime} \mathrm{S}$ and $39^{\circ} 24^{\prime} \mathrm{W}$ ), Estado do Ceará. A análise laboratorial do trato respiratório das serpentes amostradas indicou diferenças nas taxas de infecção: quatro indivíduos de P. nattereri (36.4\%) estavam infectados por Cephalobaena tetrapoda Heymons, 1922 (intensidade de infecção média de $1.5 \pm 0.28,1-2)$ e três $(27.3 \%)$ por Raillietiella furcocerca (Diesing, 1863) $(2.3 \pm 1.32$, 1-5). Apenas um indivíduo de M. ibiboboca (25\%) estava infectado por uma espécie não identificada de Raillietiella sp. Essas informações constituem os primeiros dados sobre infecção por pentastomídeos em serpentes para a região do nordeste brasileiro e ambas as espécies de serpentes constituem novos hospedeiros para os pentastomídeos identificados. Os resultados também indicam que os parasitas generalistas $C$. tetrapoda e $R$. furcocerca compartilham seus hospedeiros definitivos.

Palavras-chave: endoparasitas, Cephalobaena, Raillietiella, região neotropical.

\section{Introduction}

Pentastomids are important endoparasites of the respiratory system in vertebrates. At present, about 131 species have been described (Almeida and Christoffersen, 1999) and it is estimated that some $70 \%$ of those utilize snakes as their definitive host (Storch, 1993). Most of the studies published on pentastomids are taxonomical with very few providing data on their ecology and rates of infection. This usually results from the fact that most studies are based on the autopsy of specimens from museums and serpentariums. Furthermore, geographic records are often unreliable, given that in many instances the locality given is the museum in which the specimens autopsied were deposited (Self, 1969; Riley, 1986).

In Brazil, despite its geographical dimensions and markedly biological diversity, as little as four species of pentastomids have been reported as being parasites of snakes, Cephalobaena tetrapoda Heymons, 1922, Kiricephalus coarctatus (Diesing, 1850), Porocephalus crotali (Humboldt, 1808) and Raillietiella furcocerca (Diesing, 1863) (Table 1). These species are considered 
Table 1. Pentastomids living as parasites on snakes of Brazil.

\begin{tabular}{lll}
\hline \multicolumn{1}{c}{ Pentastomids } & \multicolumn{1}{c}{ Hosts } & \multicolumn{1}{c}{ References } \\
\hline Cephalobaena tetrapoda & Crotalus terrificus, Liophis lineatus & $\begin{array}{l}\text { Motta (1963a), Rego (1983); } \\
\text { Almeida et al. (2006) }\end{array}$ \\
Raillitiella furcocerca & $\begin{array}{l}\text { Boa constrictor, Coluber lichtensteinii, } \\
\text { Drymarchon corais, Crotalus terrificus, } \\
\text { Xenodon merremii, Lachesis sp. }\end{array}$ & Motta (1963b), Rego (1983) \\
& $\begin{array}{l}\text { Dryadophis bifossatus, Aporophis lineatus, }, \\
\text { Kiricephalus coarctatus }\end{array}$ & Sambon (1922a), Rego (1981) \\
& Crotalus terrificus & Sambon (1922a), Heymons, (1935), \\
& & Rego (1981, 1984)
\end{tabular}

generalist parasites as they have been reported as parasitizing snakes belonging to several genera and families of snakes, which in turn present distinct diets, ranging from arthropods to vertebrates (Sambon, 1922b; Heymons, 1935; Motta, 1963a, b; Rego, 1981, 1983, 1984; Almeida and Christoffersen, 2002; Almeida et al., 2006).

Prevalence and intensity of infection can provide a first approach to the understanding of the impact of parasitism on natural populations (Amo et al., 2005a, b). Nevertheless, the only data available for Northeastern Brazil are provided by Almeida et al. (2006) in a study of the colubrid Liophis lineatus. Furthermore, there is no data on how generalist pentastomids share different sympatric hosts.

This study aims to provide some ecological information regarding the rates of infection of two snake species from the semi-arid region of Brazil, evaluating which pentastomid species are associated to each host species studied providing data on prevalence and infection intensities in them.

\section{Material and Methods}

Snakes belonging to two species, Micrurus ibiboboca (Elapidae) and Philodryas nattereri (Colubridae), were captured in the field between January and April of 2005. Snakes were captured using standard herpetological methods, such as pitfalls and active search (Auricchio and Salomão, 2002) in the municipality of Crato, Ceará, Brazil ( $07^{\circ} 14^{\prime} \mathrm{S}$ and $\left.39^{\circ} 24^{\prime} \mathrm{W}\right)$. The study area is situated in the south of the state of Ceará, Northeast of Brazil (Figure 1). The site of collection is an Environmental Protection Area (Área de Proteção Ambiental - APA) of IBAMA (the Institute for the Environment and Natural Resources). Vegetation in the study area is characterized as a "Humid Forest Complex" (pluvio-nebular tropical subperennial forest), with annual average temperatures varying between 24 and $26{ }^{\circ} \mathrm{C}$. The wet season extends between January and May and the annual average precipitation is $1090.9 \mathrm{~mm}$ (IPECE, 2005). The herpetofauna consists of species common to the Amazon Forest, to the Atlantic Forest, and to the 'Caatinga', some of them being endemic species (Rodrigues, 2003).

Upon collection, the snakes were euthanized with ether and their snout-vent length (SVL) measured with

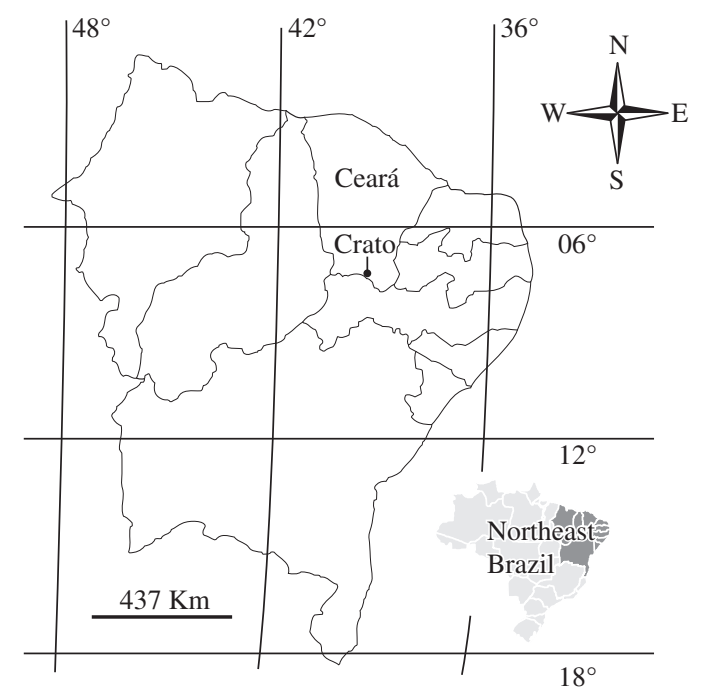

Figure 1. Location of the study area in Northeast Brazil. The municipality of Crato (Ceará, Brazil) is indicated by the black dot.

a caliper (to the nearest $0.1 \mathrm{~mm}$ ). The snakes were fixed in formalin $10 \%$ and preserved in ethanol $70 \%$ being subsequently identified according to Vanzolini et al. (1980). After the preservation treatment, they were housed in the Collection of the Zoology Laboratory of the Universidade Regional do Cariri (LZ-URCA): M. ibiboboca LZ-URCA 0110-112, 0116, and P. nattereri LZ-URCA 0089, 0090, 0098-105, 0107).

The respiratory tract of the snakes was removed and the search for pentastomids was performed under a stereomicroscope. The pentastomids found were cleared in Hoyer's medium, temporarily slide-mounted and preserved in ethanol $70 \%$, and housed in the collection of the LZ-URCA and numbered as 0157-170.

Identification of the parasites was based on the dimensions of the hooks and male copulatory spicules (see Rego, 1983, 1984; Ali et al., 1984a, b, 1985). During the identification of individuals, we also compared the specimens with material from the Helminthological Collection of the Oswaldo Cruz Institute (CHIOC) for confirmation of identity: Cephalobaena tetrapoda (29185a-d, 29190a-1), Raillietiella freitasi (Motta and Gomes, 1968) 
(20420, 20421, 20429, 20431, 20432, 20434, 20439, 30325a-c, 30326, 30327, 30328, 30329a-c, 30330a-b), $R$. furcocerca (31899a-c); and material from the LZURCA: C. tetrapoda (0043-0044) and R. gigliolii Hett, 1924 (0099-0101). Eco-parasitological terms used in this study followed Bush et al. (1997).

Our host samples can be considered as relatively homogeneous, since all snakes were collected within a relatively short period of time. Descriptive statistics are always given as the arithmetic mean \pm one standard deviation. For each pentastomid species, the number of individuals (infection intensity) was correlated with snake snout-vent length (SVL) and host sex using simple regression analyses.

\section{Results}

A total of fifteen snakes were collected during the study period, being four Micrurus ibiboboca and eleven Philodryas nattereri. The parasite species found infecting the P. nattereri were Cephalobaena tetrapoda and Raillietiella furcocerca. Micrurus ibiboboca was infected by only one non-identified species of Raillietiella sp. These specimens represent new host records for the observed species of pentastomids.

The parasites collected were adults, as the uterus of females were full of eggs and they had simple hooks with no chitinous accessories, in opposition to nymphs, which have double hooks and chitinous accessories (Riley, 1986).

Of the fifteen collected snakes, eight $(53.33 \%)$ were infected with pentastomids. In the sampled specimens of P. nattereri, 36.4\% (4/11) were infected with C. tetrapoda and $27.3 \%$ (3/11) were infected with $R$. furcocerca. Only one individual of $M$. ibiboboca (25\%) was infected by a non-identified species of Raillietiella sp. (Table 2).

The average snout-vent length (SVL) between infected and non-infected individuals of Philodryas nattereri did not differ significantly $(t$-test $=0.72 ; \mathrm{df}=9$; $\mathrm{p}=0.48$ ). Also, the average SVL was not significantly different between males and females of this host species $(t$-test $=0.82 ;$ d.f. $=8 ; \mathrm{p}=0.43)$.

\section{Discussion}

Results from the present study suggest a high prevalence of parasitic pentastomids in Philodryas nattereri and a relatively mild rate of infection for Micrurus ibiboboca, the latter being similar to the rate of infection of C. tetrapoda found in Liophis lineatus by Almeida et al. (2006) with prevalence $16.7 \%$ (1/6) and mean intensity 2 (1-2). The diet of the species belonging to the genera Liophis and Philodryas from the semi-arid region of Brazil is similar to the diet of individuals belonging to the same genera elsewhere in Brazil, which consists mostly of vertebrates (amphibians and lizards) (Vanzolini et al., 1980; Martins and Oliveira, 1999; Hartmann and Marques, 2005). This may explain the similarities in the occurrence of Cephalobaena tetrapoda in Liophis lineatus and Philodryas nattereri. Differences in diets and habitat of individuals of Micrurus ibiboboca (these are fossorial snakes, that feed on other snakes and vertebrates; Vanzolini et al., 1980; Author's personal observation) are probably the cause of the presence of an unidentified species of Raillietiella sp. (most likely a new species), distinct from $R$. furcocerca in body and hook sizes.

McAllister et al. (1993) found rates of infection by pentastomids (Raillietiella belohaensis) of $17 \%$ in a Madagascar Colubridae, Mimophis mahfalensis (Grandidier, 1867). Such rate is considerably lower that the one found in the present study. A similar prevalence of infection by pentastomids to that which we found in the present study was found by Martínez et al. (2000) among snakes from northeastern Argentina. The lowest prevalence of infection reported by Martínez et al., (2000) was for Eunectes notaeus Cope, 1862 (only 7\%), which is lower than the lowest score reported in this study. Apart from cases where only one individual was collected, the prevalence of infection by pentastomids reported by Martínez et al. (2000) ranged from 30\% to $80 \%$ of sampled individuals. The range of prevalence found in this study conforms well with Martínez et al.'s (2000) data.

Nevertheless, it is noteworthy that despite similar and different rates of infection between the present study and the studies of McAllister et al. (1993) and Martínez et al. (2000), our results are highly associated to local climatic and habitat characteristics. Furthermore, it is important to note that the mentioned authors used different sampling methods, which may result in differences in the encountered rates of infection by endoparasite communities (Haukisalmi and Henttonen 1998), given that the study of McAllister et al. (1993) was performed in another continent (with different fauna and flora) and is based on a relatively small sample size. Data from Martínez et al. (2000) on prevalence of infection represent the only

Table 2. Epidemiological data for snakes (sample sizes in parentheses) and their respective pentastomid parasites in Northeastern Brazil. For each host species (overall and by species), the mean SVL, (range in mm), prevalence (in absolute values and proportions) and intensity of infection (mean \pm one standard deviation, with range in parentheses) are presented.

\begin{tabular}{cllcc}
\hline Host species (n) & Mean SVL (range mm) & \multicolumn{1}{c}{ Pentastomida } & Prevalence (\%) & $\begin{array}{c}\text { Mean intensity } \\
\text { (range) }\end{array}$ \\
\hline Philodryas nattereri (11) & $90.66 \pm 5.16(69-109)$ & C. tetrapoda & $4(36.4)$ & $1.5 \pm 0.28(1-2)$ \\
& & Raillietiella furcocerca & $3(27.3)$ & $2.3 \pm 1.32(1-5)$ \\
Micrurus ibiboboca (04) & $65.25 \pm 15.77(37-110)$ & Raillietiella sp. & $1(25)$ & 1 \\
\hline
\end{tabular}


comparable information available from South America to the present study. Nevertheless, results from Martínez et al. (2000) were obtained from collections in a different area and specimens were sampled from several localities across the northeastern region of Argentina. Therefore, the results presented in this study and by Almeida et al. (2006) represent the only ecological information available on pentastomid parasitism in snakes for Northeastern Brazil, which highlights the need for further investigations in different ecosystems in order to find patterns of prevalence and intensity of infection for ophidians in South America.

Acknowledgments - We thank Dra. Dely Noronha, curator of the Helminthological Collection of the Instituto Oswaldo Cruz, for the loan of pentastomid specimens. The authors acknowledge the financial support in the form of scholarships and a research grant received from FUNCAP - Fundação Cearense de Apoio ao Desenvolvimento Científico e Tecnológico (Ref. 943/03 Edital 003/03) and for scholarship support for Suzana Gomes Lopes. Thanks to IBAMA - the Brazilian Institute for the Environment and Natural Resources - for their permission to collect samples from protected areas (080/04 - RAN/ IBAMA Processo 02007.001009/04-73); to Eldo Marinho de Menezes, Samuel Vieira Brito and Felipe Silva Ferreira for their help with field and laboratory work; to Dr. Elvio Medeiros (UEPB) for the translation of the manuscript to English and to Dr. Jörn Seemann (URCA) for revising the English version of the text. We also thank one anonymous reviewer for valuable suggestions and criticisms on the manuscript.

\section{References}

ALI, JH., RILEY, J. and SELF, JT., 1984a. A revision of the taxonomy of pentastomid parasites (genus Raillietiella Sambon, 1910) from American snakes and amphisbaenians. Syst. Parasitol., vol. 6, p. 87-97.

-, 1984b. Further observations of blunt-hooked raillietiellids (Pentastomida: Cephalobaenida) from lizards with descriptions of three new species. Syst. Parasitol., vol. 6, p. 147-160.

-, 1985. A review of the taxonomy and systematics of the pentastomids genus Raillietiella Sambon, 1910 with a description of a new species. Syst. Parasitol., vol. 7, p. 111-123.

ALMEIDA, WO. and CHRISTOFFERSEN, ML., 1999, A cladistic approach to relationships in Pentastomida. J. Parasitol., 85(4):695-704.

-, 2002. Pentastomida, p. 187-202. In MORRONE, J. and LLORENTE-BOUSQUETS, J. (eds.), Biodiversidad, Taxonomía y Biogeografía de Artrópodos de México: Hacia una síntesis de su conocimiento, vol. 3. Universidad Nacional Autónoma de México, México, 690p.

ALMEIDA, WO., BRITO, SV., FERREIRA, FS. and CHRISTOFFERSEN ML., 2006. First record of Cephalobaena tetrapoda (Pentastomida: Cephalobaenidae) as a parasite on Liophis lineatus (Ophidia: Colubridae) in Northeastern Brazil. Braz. J. Biol., vol. 66, no. 2a, p. 559-564.

AMO, L., FARGALlO, J.A., MARTÍNEZ-PADILLA, J., MILLÁN, J., LÓPEZ, P. and MARTÍN, J., 2005a. Prevalence and intensity of blood and intestinal parasites in a field population of a Mediterranean lizard, Lacerta lepida. Parasitol. Res., vol. 95, p. 413-417.
AMO, L., LÓPEZ. P. and MARTÍN, J., 2005b. Prevalence and intensity of haemogregarine blood parasites and their mite vectors in the common wall lizard, Podarcis muralis. Parasitol. Res., vol. 96, no. 378-381

AURICCHIO, P. and SALOMÃO, MG. (Orgs.), 2002. Técnicas de coleta e preparação de vertebrados para fins científicos e didáticos. Instituto Pau Brasil de História Natural, São Paulo, $348 \mathrm{p}$.

BUSH, AO., LAFFERTY, KD., LOTZ, J. and SHOSTAK, AW., 1997. Parasitology meets ecology in its own terms: Margulis et al. revisited. J. Parasitol., vol. 83, p. 575-583.

HARTMANN, PA. and MARQUES, OAV., 2005. Diet and habitat use of two sympatric species of Philodryas (Colubridae), in South Brazil. Amphibia-Reptilia, vol. 26, p. 25-31.

HAUKISALMI, V. and HENTTONEN, H., 1998. Analysing interspecific associations in parasites: alternative methods and effects of sampling heterogeneity. Oecologia, vol. 116, p. $565-574$.

HEYMONS, R., 1935. Pentastomida, p. 1-267. In HG BRONN (ed.), Klassen und Ordnungen der Tierreichs. Leipzig, Akademische Verlagsgesellschaft.

IPECE Instituto de Pesquisa e Estratégia Econômica do Ceará, 2005. Perfil básico municipal: Crato. Governo do Estado do Ceará, Secretaria do Planejamento e Coordenação, Fortaleza.

MARTÍNEZ, FA., TROYANO, JC., GAUNA-AÑASCO, L., DUCHENE, AJS., STANCATO, MR., NUÑEZ, S., FESCINA N. and JARÁ, D., 2000. Frecuencia de infestación por pentastomídeos en ofidios. http://web.unne.edu.ar/cyt/ veterinarias/v-016.pdf.

MARTINS, M. and OLIVEIRA, ME., 1999. Natural history of snakes in forests of the Manaus region, Central Amazonia, Brazil. Herp. Nat. Hist., vol. 6, no. 2, p. 78-150.

MCALLISTER, CT., RILEY, J., FREDD, PS. and FREDD, DA., 1993. Endoparasites of some Malagasy colubrids (Reptilia: Serpentes), with description of two species of Raillietiella (Pentastomida: Cephalobaenidae). Trans. Am. Microsc. Soc., vol. 112, no. 1, p. 35-42.

MOTTA, CS., 1963a, Considerações sobre o gênero Cephalobaena Heymons, 1922 (Linguatulida), Cephalobaena tetrapoda. Atas Soc. Biol. Rio de Janeiro, vol. 7, no. 4, p. 7-8.

-, 1963b, Considerações sobre o gênero Raillitiella Sambon, 1910. Atas Soc. Biol. Rio de Janeiro, vol. 7, no. 2, p. 8-10.

REGO, AA., 1981. Notas sobre alguns pentastomídeos de répteis. Mem. Inst. Butantan, vol. 44/45, p. 233-238.

-, 1983. Pentastomídeos de répteis do Brasil: Revisão dos Cephalobaenidae. Mem. Inst. Oswaldo Cruz, vol. 78, no. 4, p. 399-411.

-, 1984. Sinopse dos pentastomídeos da região neotropical. Garcia de Orta, Série Zoologia, Lisboa, vol. 11, p. 45-46.

RILEY, J., 1986. The biology of pentastomids. Adv. Parasitol., vol. 25 , p. 45-128.

RODRIGUES, MT., 2003, Herpetofauna da caatinga, p. 181-236. In LEAL, IR., TABARELLI, M. and da SILVA, JMC.(eds), Ecologia e conservação da caatinga. Recife: Ed. Universitária da UFPE, 822p.

SAMBON, LW, 1922a. A synopsis of the family Linguatulidae II. J. Trop. Med. Hyg., vol. 25, p. 188-206. 
-, 1922b. A synopsis of the family Linguatulidae. J. Trop. Med. Hyg., vol. 2, p. 391-428.

SELF, JT., 1969. Biological relationships of the Pentastomida; a bibliography of the Pentastomida. Exp. Parasitol., vol. 24, p. $63-119$.

STORCH, V., 1993, Pentastomida, p. 115-142. In HARRISON,

FW. and RICE, ME. (eds), Microscopic anatomy of inver- tebrates: Onychophora, Chilopoda, and lesser Protostomata, vol. 12, Wiley-Liss, New York.

VANZOLINI, PE., RAMOS-COSTA, AMM. and VITT, LJ., 1980. Répteis das caatingas. Academia Brasileira de Ciências, Rio de Janeiro, 161p. 